\title{
INOVA
}

Working Paper

\# 630

2019\#

NOVA

School

of Business

\& Economics

Shaping

powerful

minds
The impact of

Airbnb on

residential

property values

and rents:

Evidence from

Portugal

Sofia F. Franco

Carlos Daniel Santos

Rafael Longo 


\section{The Impact of Airbnb on Residential Property Values and Rents: Evidence from Portugal ${ }^{\ddagger}$}

\author{
Sofia F. Franco*
}

\author{
Carlos Daniel Santos**
}

May $8^{\text {th }}, 2019$

\author{
Rafael Longo***
}

\begin{abstract}
Short-term rentals have facilitated the upraise trend in tourism growth in several cities around the world. However, concerns for the negative effects that such home-sharing platforms may have on the housing market and traditional markets have driven community groups and housing advocates to intensely react against them. Whether or not shortterm rentals increase housing prices and rents for local residents is an empirical question. We quantify the causal effects of Airbnb's short-term rentals on urban housing affordability in Portugal by estimating quarterly housing rents and prices as a function of Airbnb concentration. We take advantage of the 2014 regulatory reform and employ a differencein-differences (DiD) empirical strategy. We estimate an overall increase in property values of $34 \%$ and $10.9 \%$ for rents due to the short-term lease regulatory reform. We also find that these effects are particularly localized to the historical centers and areas attractive to tourists in the cities of Lisbon and Porto. A better understanding of the effects of shortterm home rentals on housing markets and of the magnitude of its impact on residential property prices and rents are crucial information to determine whether it needs to be regulated and how proper regulation should be designed.
\end{abstract}

Keywords: Property Values, Airbnb, Short-term Rentals, Regulation

JEL codes: R21, R31, Z32

${ }^{\ddagger}$ Financial support by FCT (Fundação para a Ciência e a Tecnologia), Portugal, is gratefully acknowledged. This article is part of the Strategic Project UID/ECO/00124/2013, and it is also financed by POR Lisboa under the project LISBOA-01-0145-FEDER007722.

* Nova School of Business and Economics (NovaSBE) Address: Nova School of Business and Economics, Campus de Campolide P-1099-032, Lisboa, Portugal. Email sfranco@ novasbe.pt. Phone Number: + (351) 213801600.

** Nova School of Business and Economics (NovaSBE) Address: Nova School of Business and Economics, Campus de Campolide P-1099-032, Lisboa, Portugal. Email carlos.santos@ novasbe.pt. Phone Number: + (351) 213801600.

*** Nova School of Business and Economics (NovaSBE) Address: Nova School of Business and Economics, Campus de Campolide P-1099-032, Lisboa, Portugal. Phone Number: + (351) 213801600. 


\section{Introduction}

While a beautiful image of a city is one of the backbones for tourism, peer-to-peer online marketplaces that facilitate matching between demanders and suppliers of short-term rentals such as Airbnb, Homestay or Bedycasa have facilitated the upraise trend in tourism growth in several cities around the world. However, concerns for the negative effects that such home-sharing platforms may have on the housing market and traditional markets have driven community groups and housing advocates to intensely react against them.

Critics of Airbnb and of similar home-sharing platforms argue that these platforms increase home prices by restricting the supply of long-term rentals exacerbating local affordability issues (Lee 2016) and, present unfair competition to traditional suppliers of short-term lodging such as hotels (Zervas et al. 2017). In fact, hotel associations complain that short-term home rentals function as hotels but have the unfair advantage of not paying taxes or comply with safety and zoning regulations. Critics further allege that home-sharing platforms can contribute to racialized gentrification as some hosts are prone to reject certain minority groups (Edelman and Luca 2014, Edelman et al. 2017) and, also to a decrease on resident's quality of life due to noise, congestion, safety concerns and competition for scarce parking, as neighborhoods get transformed into hotel districts (Cocola-Gant 2016). Moved by these concerns, attempts have been made to regulate or even to ban provision of these services in several cities around the world. ${ }^{1}$ On the other hand, those who favor home-sharing platform's rentals tend to focus on its positive economic impact on the city, including creating new income streams for residents as well as encouraging the rehabilitation of the housing stock and tourism and its associated economic benefits for a city as a whole (Kaplan and Nadler 2015).

The goal of this paper is to provide empirical evidence to this debate by quantifying the causal effects of Airbnb's short-term home rentals on urban housing affordability in Portugal. In recent year, national prices of long-term housing have been rising faster than overall consumer prices and wages. Moreover, because demand for housing is relatively inelastic, small changes in housing supply can cause significant changes in the cost of housing (Albouy et al. 2016). This inelastic behavior generates concerns over its impact on consumer welfare. The increase in the cost of long-term housing has then become a much-discussed policy challenge that has spurred much debate on the impacts that Airbnb may have on housing affordability.

To identify the causal impact of Airbnb concentration on house prices and rents, we take advantage of the Portuguese 2014 regulatory reform Decreto-Lei $n .^{\circ}$ 128/2014 and employ a difference-in-differences (DiD) empirical strategy. The 2014 regulatory reform greatly simplifies the process of entering into the

\footnotetext{
${ }^{1}$ Some cities have laws that restrict the ability to host paying guests for short periods (e.g. Amsterdam, New York, Paris, San Francisco). In many other cities, the host must register (e.g. Lisbon), get a permit (e.g. Barcelona, Berlin, Paris and San Francisco), or obtain a license (e.g. Cape Elizabeth) before the host lists the property or accepts guests. Certain types of short-term bookings may be prohibited altogether (e.g. Berlin and New York) and in other cases the measures include paying a rental tax (e.g. Amsterdam and San Francisco). Local governments vary greatly in how they enforce these laws, but penalties may include fines or other enforcement.
} 
short-term sublet business in Portugal. It consists of a change in legislation to simplify a series of bureaucratic procedures to a situation that requires only a pre-registration of the property with the Portuguese Registry Office of Short-Term Rentals before the host lists the property on a hosting platform or accepts guests. This change in the rental policy realm has in turn induced effects to the nationwide housing market by facilitating the operation of informal vacation rentals. Moreover, the policy change generates an exogenous source of variation to the number of Airbnb listings in Portugal that allows us to circumvent the endogeneity issues that are inherent to this type of research.

Using data we collected from Airbnb, quarterly housing rents and prices from approximately 100 municipalities in Portugal dating back to 2010, and several other auxiliary datasets to compile controls, we thus quantify the extent to which Airbnb listings concentration has impacted house prices and rents in the country. We pay particular attention to Lisbon and Porto, the two main cities in the country which have experienced both rapidly rising housing costs and growth in Airbnb listings since 2011. Our DiD strategy identifies the Airbnb treatment effect by comparing differences in house prices in municipalities differentially affected by Airbnb before and after the regulatory reform for the period 2011-2016. For robustness we also report results from an instrumental variable strategy similar to Barron et al. (2018). In that case, the proportion of Airbnb houses on a given municipality in a given quarter are instrumented by the online search for Airbnb on Google. The instrument is the interaction of Google time trends for the word "Airbnb" with the share of properties on Airbnb in the first quarter of 2014 (before the policy change).

We find an overall increase in property values of $34 \%$ and $10.9 \%$ for rents due to the 2014 regulatory reform. These magnitudes can also be translated into percent changes in Airbnb presence. As such, a $1 \%$ increase in the Airbnb listing rate (that is, in the share of Airbnb listings to the number of housing units) results in a $4.5 \%$ average increase in property values and a $2.26 \%$ increase in rents. Our results are robust to wide range of placebo-tests and specification alternatives. Furthermore, we also find that these effects are particularly localized to the historical centers and areas attractive to tourists in the cities of Lisbon and Porto.

\section{Portugal as a case study}

Portugal is an interesting case to study. The country is currently experiencing a tourism boom that boosts the economy, but also puts added strains on municipal services and affordable housing for local residents. ${ }^{2}$

However, while some European cities were tightening regulations applied to short-term rentals via websites to keep housing affordable and protect residents from noisy visitors, Lisbon took steps in 2014 to

\footnotetext{
${ }^{2}$ According to the 2018 latest statistics made available by the Institute for Tourism Planning and Development (IPDT), Lisbon and Porto have a higher ratio of tourists to residents than renowned tourist spots Barcelona and Prague. Lisbon averages 4.5 million tourists per year, meaning that for every resident there are typically 9 tourists. Porto welcomes 1.6 million tourists annually, the equivalent of 8 visitors per local. The ratio is even higher in Albufeira in the Algarve region on Portugal's south coast, where tourists outnumber locals by 39 to 1 .
} 
make short-term rentals easier. ${ }^{3}$ Government measures including phasing out rent controls and selling hundreds of empty buildings at public auctions have also helped support a rebirth of cities and the proliferation of short-term rentals since $2012 .{ }^{4}$ Moreover, the 2014 end of the year reform of Portaria $n .^{o}$ 517/2008 and Decreto-Lei $n .^{\circ} 15 / 2014$, the then existing Portuguese laws regulating the ability to host shortterm paying guests, has greatly simplified the licensing process of short-term rentals.

The law, Decreto-Lei $n .^{\circ} 128 / 2014$, mandates only a pre-registration of the unit with the Portuguese Registry Office of Short-Term Rentals (Registo Nacional de Estabelecimentos de Alojamento Local RNAL) before the host (whether it is a large establishment such as a hotel or simply rooms in a private home that are occasionally rented) lists the property on a hosting platform or accepts guests. This has made the process of entering into the short-term sublet business in Portugal and in particular the operation of informal vacation rentals at the time simpler and faster.

According to RNAL, the number of legal short-term sublets in Portugal increased from 13 thousand as of December 2014 to more than 55 thousand units as of December 2017. ${ }^{5}$ The majority of these registrations are concentrated in the municipalities of Lisbon (10.611), Porto (4.881) and Albufeira (4.815).

\section{Related Literature}

While local amenities (e.g. city parks, water bodies, cultural and historic amenities, noise) explain some of the variability in house prices within and across cities (Franco and Macdonald 2018a,b), quantity restrictions, natural geographic barriers and housing renewal programs have also been shown to impact property prices through a supply effect (Saiz 2010, Quigley and Raphael, 2005, Ihlanfeldt, 2007). Channels from both demand and supply sides can therefore contribute over time for the observed trend in rents and

\footnotetext{
${ }^{3}$ For example, in 2014 Barcelona's local government imposed a moratorium on the concession of permits for shortterm rentals in an extended area in central Barcelona. Since then the number of legal short-term rentals in Barcelona has been frozen at 9600 units (Segu 2018).

${ }^{4}$ In 2012 a new urban lease law was enacted in Portugal to liberalize old rent contracts. The goal of this regulation was to remove market distortions that are the legacy of a complex succession of rent laws going back decades and thus, by removing rent freezes the reform hoped to increase the quality of the existing housing stock. The legislation set a fiveyear period of transition from the old lease contracts to the new regime of free rent, and introduced measures to broaden the conditions under which renegotiation of open-ended residential leases could take place. The 2012 legislation, in turn, followed the implementation of a new model of urban rehabilitation in Portugal that started in 2004 with new incentives to stimulate private housing rehabilitation, especially in historic districts, and with the creation of urban rehabilitation companies that would allow cooperation between the private and public sectors. These housing policy reforms are believed to have also resulted in substantial rent increases in the country.

${ }^{5}$ In 2017, more rigorous legislation was approved in Portugal to regulate short-term rental properties. This is outside our period of analysis. As of July 1, 2017, properties posted on Airbnb, Booking, Homeaway and other platforms need to be enrolled on the national tourism register. To be allowed to advertise on such platforms, property owners will have to fill in a required field with the registration number of their accommodation. Platforms will be subject to sanctions if they market non-registered properties. This measure was set to guarantee the rules of legal competition.
} 
house prices. However, Airbnb housing rentals can potentially exacerbate rising rent costs through both supply and demand mechanisms.

Short-term rentals can be an additional source of income for homeowners which in turn spurs the demand for housing space and rents. Moreover, by potentially leading to a reallocation of the housing stock from the long-term to the short-term markets and by generating nuisances on nearby properties, short-term rentals like Airbnb may also impact the property market. So, whether or not Airbnb rentals or other home-sharing types increase housing costs for local residents is an empirical question. A better understanding of the effects of short-term home rentals on housing markets and of the magnitude of its impact on residential prices and rents are imperative to determine whether it needs to be regulated and how proper regulation should be designed. Regulation might then be necessary to avoid the long term impacts of excessive tourism in terms of population displacement and/or excess gentrification. Besides, there might be social welfare considerations regarding the effect of house prices on the most vulnerable groups of the population.

Despite the public debate, apparent anecdotal evidence and regulatory bans, the research literature on how home-sharing impact cities and in particular the housing market is still thin, meaning that wider applicability to other cities and contexts is unclear.

Published academic studies on Airbnb are mostly tourism studies (Guttentag, 2015; Zervas et al. 2016), although some studies have also addressed the regulation of the share economy overall (Morgan and Kuch, 2015) and short-term rentals in particular (Gottlieb, 2013; Palombo, 2015). Recently Gurran and Phibbs (2017) examine the expansion of Airbnb listings in the Sydney metropolitan area, focusing on implications for urban policy and planning.

We are aware of only seven other academic papers that directly study the effect of Airbnb on housing rents and prices. With the exception of Segu (2018) who focuses her study in the city of Barcelona, the other six studies focus on either a specific US Market (see for example Lee (2016) for Los Angeles, Horn and Merante (2017) for Boston, Sheppard and Udell (2018) and Wachsmuth et al. (2018) for New York city, Koster et al. (2019) for Los Angeles County) or on the entire US Market (Barron et al. 2018). In general, this emerging literature finds that Airbnb has a measurable effect on long-term housing supply and prices in the cities where it operates, raising housing costs for local residents.

Horn and Merante (2017) use Airbnb listing data from Boston in 2015 and 2016 and, find that a one standard deviation increase in Airbnb listings relative to the total number of housing units in a census tract, is associated with a $0.4 \%$ increase in asking rents. The study further shows that for those census tracts in the highest decile of Airbnb listings relative to total housing units, this increase in asking prices ranges from $1.3 \%$ to $3.1 \%$.

On the other hand, Barron et al. (2018) study the effect of Airbnb on the long-term rental market using a dataset of all US properties listed in Airbnb between 2011 and 2016. The study uses an IV approach where 
Google trends of the search "Airbnb" is an instrument to identify the causal effect. Since this instrument is time variant but geographically invariant, the authors combined it with a measure of how "touristy" a zipcode is in a base year. The rational for this approach is that if a certain area attracts a lot of tourists and receives a sudden surge in online search interest for Airbnb, then any subsequent increase in Airbnb listings is caused by the increased demand from visitors for short-term rentals. The study finds that a one standard deviation increase in listings at the within-core based statistical area zipcode level raises rents by $0.54 \%$. The authors explain that one reason for such a small impact is that most people offering short-term rentals are owner-occupiers rather than commercial operators running mini-hotels or "hotelization" of entire buildings.

Wachsmuth et al. (2018) apply the regression results identified by Barron et al. (2018) to the increase in Airbnb rentals in New York City. They find a 1.4 percent increase in NYC rents from 2015 to 2017 due to Airbnb's expansion in that city. For the median NYC renter, this implies a $\$ 384$ annual increase in rent from 2015 to 2017 due to Airbnb's expansion over that time.

Sheppard and Urdell (2018) look also at the impact of Airbnb listings on house prices in New York. In contrast to the former studies, this study applies not only a traditional hedonic approach but also a matched difference-in-differences strategy similar to Zervas et al. (2014). ${ }^{6}$ The first approach provides measures of the associational impact of Airbnb listings, while the second approach provides a causal effect by identifying treatment and control groups within the observational data. ${ }^{7}$ Since the authors have available a large number of individual sales both before and after Airbnb's entry into the New York City market, they are able to apply quasi-experimental techniques to examine whether short-term rentals make New York City less affordable. The results from this study suggest that residential properties that are subject to the treatment of having Airbnb properties nearby when sold experienced an increase in price by $3.5 \%$ (if located far from the CBD (Wall Street) and with a treatment consisting of few Airbnb properties) to more than 65\% for properties located near Wall Street and/or treated by having a larger number of Airbnb rentals nearby.

More recently, Koster et al. (2019) apply a quasi-experimental approach to evaluate the causal impact of Airbnb properties on house prices in the context of Los Angeles County. In particular, the study uses a spatial regression discontinuity design combined with a difference-in-differences set up to examine the

\footnotetext{
${ }^{6}$ Zervas et al. (2014) have examined the impact of Airbnb on the hotel industry. The authors use a difference-indifference fixed effects strategy to identify the causal effect of Airbnb's entry into the market on hotel revenues. The authors deal with the endogeneity issue by assuming that unobserved factors that could affect both Airbnb adoption and hotel room revenue do not systematically vary between cities and over time. The authors found that a $10 \%$ increase in Airbnb units results in a $0.38 \%$ decrease in hotel revenue, which is significant if we take account the exponential increase Airbnb has experienced.

${ }^{7}$ Treatment in this study means that a sale of a residential property took place at a time when there were Airbnb properties available within 300 meters of the sale property location. The construction of treatment and control groups were based on different methods such as nearest-neighbor matching, propensity-score matching and regression adjustment.
} 
changes in the number of Airbnb listings and in house prices close to the borders of the cities that have implemented the Home-Sharing Ordinances. The authors find the ordinances strongly reduced the number of Airbnb listings by $70 \%$ in the long run and reduced house prices by $3 \%$ on average and also rents by the same amount as house prices.

Our paper contributes to this emerging literature on the effects of home-sharing on housing costs in two ways. On the one hand, our study takes advantage of a change in the Portuguese regulation of short-term rentals that affected not just the most important municipalities in Portugal but also the entire country. This in turn enables us to use a difference-in-differences approach to assess and quantify the causal effect of Airbnb listings in house prices and rents using a comprehensive dataset for a European country and assess more broadly the effects of Airbnb on housing affordability. We further check the robustness of our results using also an IV approach similar to Barron et al. (2018). In addition, while previous studies concentrate on the effects of strict short-rental regulations for short-term rentals in a particular city (see for example Koster et al. 2019), our study explores how loosen short-term housing rental regulations impacted the number of Airbnb listings and its effects on property and rental prices not only on major cities and touristy areas but overall in the country.

The rest of the paper is organized as follows: section 2 provides an overview of the housing market in Portugal. Section 3 discusses our data sources, provides descriptive statistics and presents our identification strategy. We report and discuss our main results in section 4 , followed by robustness checks of our findings. Finally, Section 5 offers conclusions.

\section{Overview of the Housing Market in Portugal}

This section offers a brief overview of the housing market in mainland Portugal by focusing on the two key features of the Portuguese housing market - trends of house prices and rents and spatial distribution of short-term rentals- that provide a context to our research. We focus only on mainland Portugal because we lack data on house prices and rental prices for the Portuguese island regions of Azores and Madeira. ${ }^{8}$

We define as Alojamento local (AL) or short-term rentals any private property with less than 10 rooms that is offered on a short-term rent to either national or foreign tourists. Moreover the property is let out one or more times a year for a period that typically exceeds one month i.e. summer or winter let outs. But they can also be rented for days, weeks or months. All housing properties meeting this definition must also obey the holiday rental laws which seek to regulate short-term let out properties from private individuals and bring them in line with minimum lodging standards.

\footnotetext{
${ }^{8}$ Continental Portugal or mainland Portugal are terms used for the bulk of the Portuguese Republic, namely that part on the Iberian Peninsula and so in Continental Europe, having approximately $95 \%$ of the total population and $96.6 \%$ of the country's land.
} 
Before illustrating the distribution of house prices and short-term rentals across administrative divisions of mainland Portugal over time, it is important to mention that the Portuguese constitution identifies three tiers of government: civil parishes (freguesias), municipalities (municípios) and administrative regions (regiões administrativas). The current administrative divisions of Portugal, are the 18 Districts in mainland Portugal and the 2 Autonomous Regions of Azores and Madeira. In Portugal, there are also 308 municipalities (272 in mainland) and 3092 parishes (2882 in mainland). The Lisbon Metropolitan Area consists of 18 municipalities with a total population (2011 census) of 2,821,876. The Metropolitan Area of Porto consists of 17 municipalities with a total population (2011 census) of 1,759,524. Total population in the country (2011 census) is $10,562,178$.

\subsection{Prices in the Long-Term Housing Market}

House prices in the long-term residential market, as measured by transaction prices, have increased 14\% in Lisbon from the $1^{\text {st }}$ quarter of 2011 (2011Q1) to the $1^{\text {st }}$ quarter of 2016 (2016Q1), while decreasing 20\% in Porto and $12 \%$ in the rest of mainland Portugal. This discrepancy between Lisbon and the rest of the country can be better observed in Figure 1, where house prices in Lisbon and Porto are compared to the rest of mainland Portugal. The vertical line marks the date of the policy reform with the publication of DL128/2014.

In line with anecdotal evidence, Figure 1 provides graphical evidence that there has been a change in the behavior of transaction prices after the change in the short-term rental regulation in the $3^{\text {rd }}$ quarter of 2014 (2014Q3), particularly for the cities of Porto and Lisbon.

However, it is important to note that until 2011 Portugal had very solid rent controls in place that left little incentive for landlords to maintain properties, and high housing sales tax rates discouraged them also from wanting to sell. As a result, many buildings, particularly buildings in historic areas, were left relatively dilapidated and run-down. Then, in 2011, Portugal entered into a severe economic crisis that made the country unable to repay or refinance its government debt, resulting in a $€ 78$ billion bailout program. In 2012, rent controls were rolled back considerably as a condition of the bailout program. ${ }^{9}$ In the meanwhile, the country entered into a significant tourism boom that has changed the landscape of Portugal, particularly in Lisbon and Porto. ${ }^{10}$ Thus, to isolate the effect of the 2014 short-term policy reform from the confounding effect of the rental market liberalization, we explore the differential evolution of house prices and rents in areas with touristic potential with the evolution of house prices and rents in areas with no touristic potential,

\footnotetext{
${ }^{9}$ In addition, a "golden visa" program was also launched whereby foreigners can invest in Portugal in a variety of ways such as buying real estate properties valued at $€ 500,000$ or more, in exchange for resident permits. The "golden visa" program has driven a total investment of around $€ 3.8$ billion as of April 2018, about $€ 3.4$ billion of which has been via purchases of property.

10 The annual international arrivals to Portugal went from 4.8 million in 1997 to almost 13 million in 2017.
} 
leading to our DiD specification. To identify the causal effect of Airbnb listings on house prices and rents, there must be touristic pressure which in turn leads to an increase in the demand for short-term rentals.

Figure 1: Transaction Prices, in $€$ per $\mathrm{m}^{2}$, in Lisbon, Porto and the rest of Mainland Portugal.

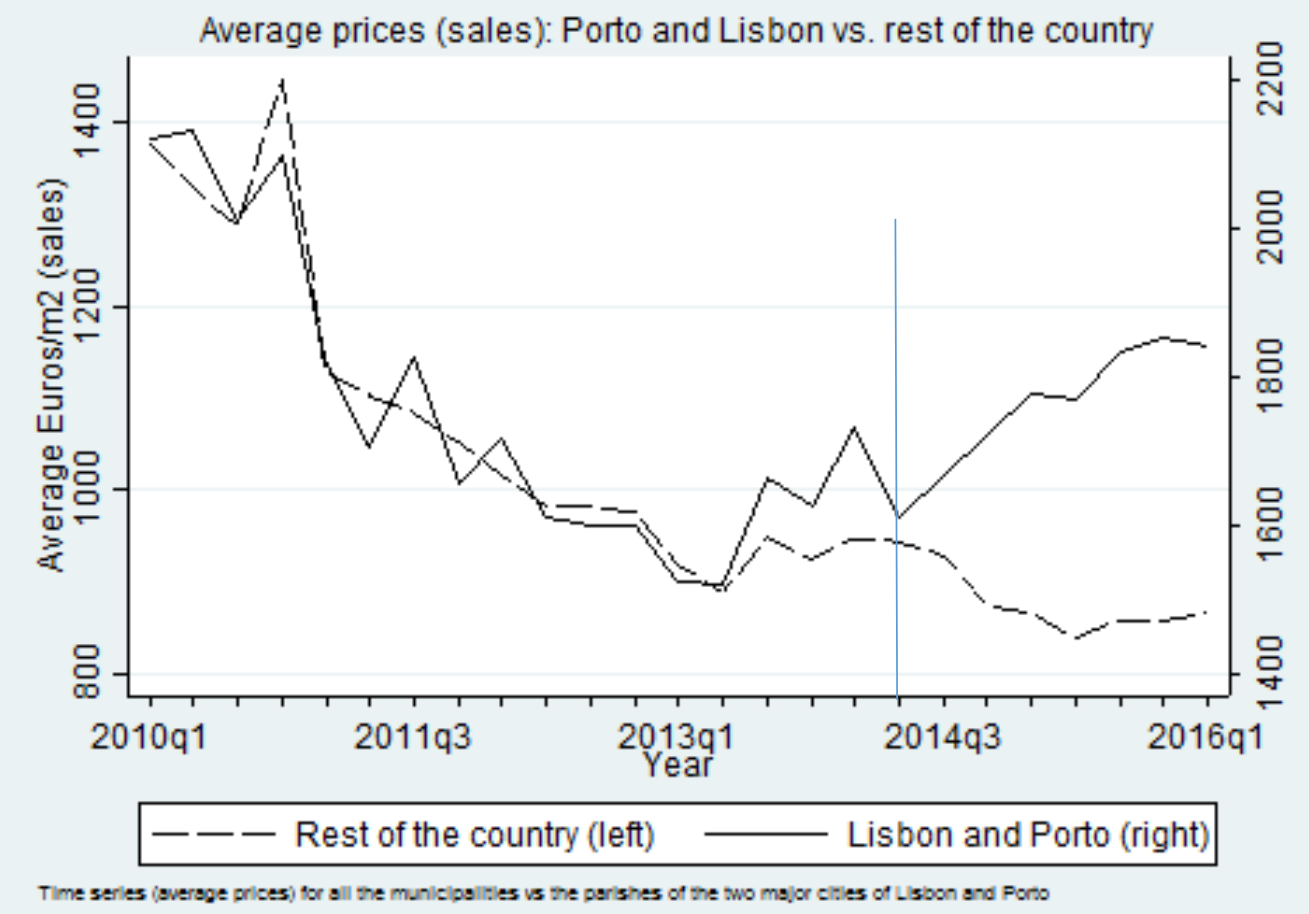

In Figure 2, we illustrate the behavior of long-term rental prices over time. It is clear that a similar, though less pronounced pattern as that observed for transaction prices, also emerges in rental prices. Between the $3^{\text {rd }}$ quarter of 2014 (2014Q3) and the $1^{\text {st }}$ quarter of 2016 (2016Q1), rental prices increased from about $7.9 € / \mathrm{m}^{2}$ in Lisbon and Porto, and $4.7 € / \mathrm{m}^{2}$ in the rest of the country, to about $9.1 € / \mathrm{m}^{2}$ in Lisbon and Porto and $5 € / \mathrm{m}^{2}$ in the rest of the country.

Figure 3 explores house price trends across civil parishes with small versus large presence of short-term rentals within the two largest cities in Portugal, Lisbon and Porto. These cities have very diverse neighborhoods, and therefore looking solely at citywide trends masks significant variation. 
Figure 2: Value of rents, in $€$ per $\mathrm{m}^{2}$, in Lisbon, Porto and the rest of Mainland Portugal.

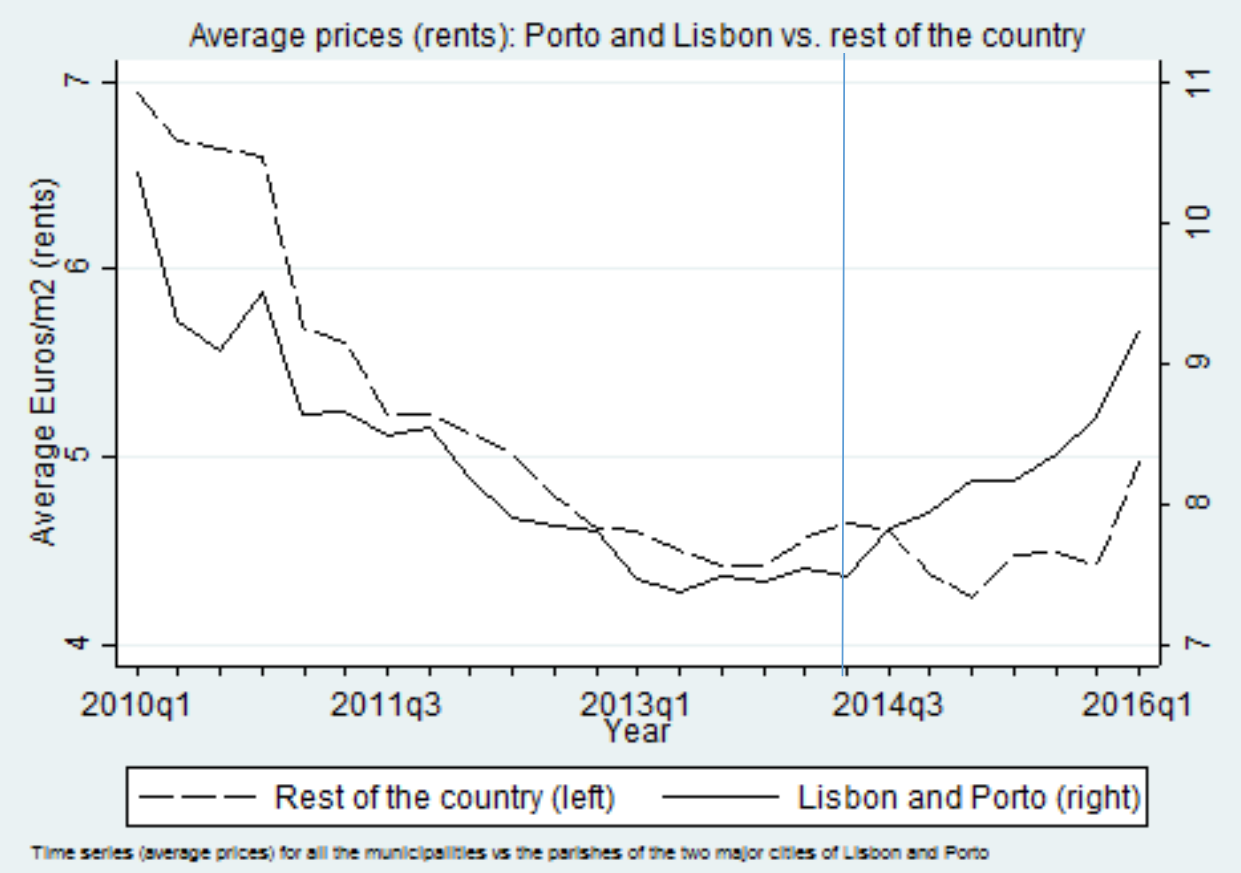

Figure 3: Transaction Prices, in $€$ per $\mathbf{m}^{2}$, in civil parishes within Lisbon, Porto.

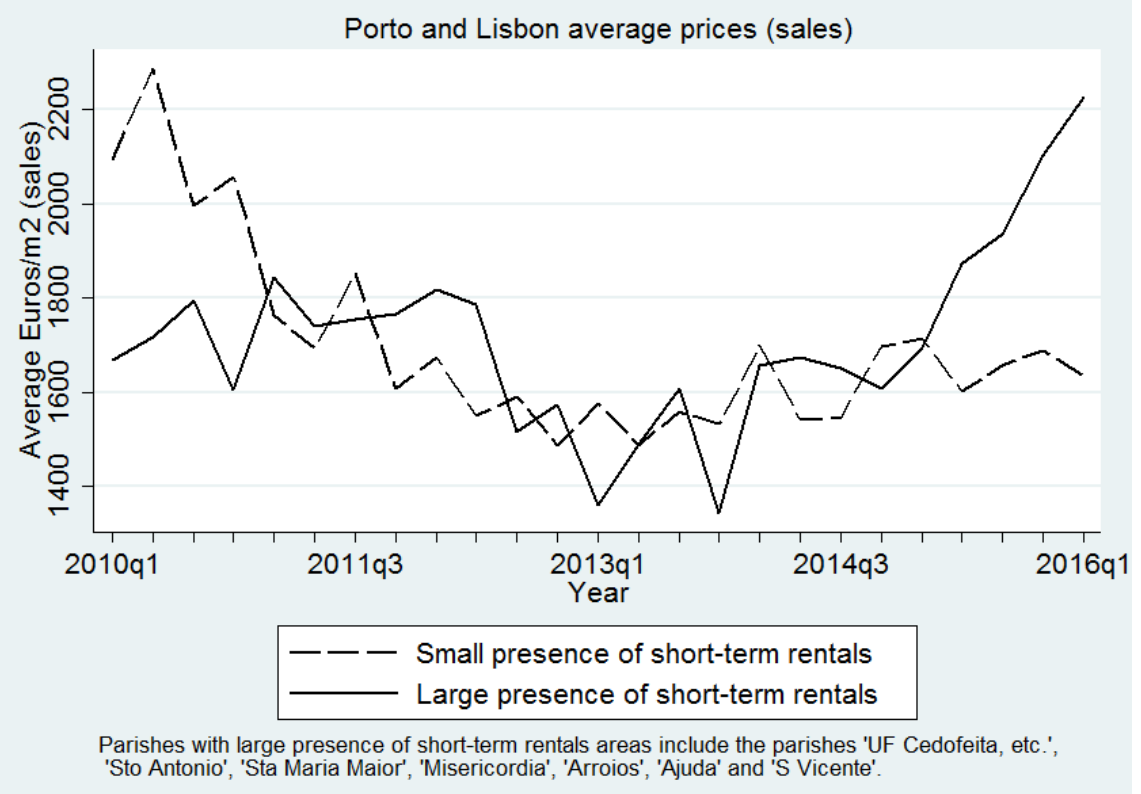


It is clear from Fig. 3 that before the policy reform transaction prices were already increasing in both areas, with large and small presence of short-term rentals. Market liberalization may help explain the trend observed in both areas right before the policy change in 2014Q3. However, what is striking is that after the policy change in 2014Q3, areas with large presence of short-term rentals exhibit the strongest transaction price increases. It is this differential evolution in transaction prices that allows us to infer the causal effect of the 2014 policy change.

Figure 4: Transaction price in $€$ per $\mathrm{m}^{2}$, in the $1^{\text {st }}$ quarter of 2015, in Mainland Portugal (on the right), Porto (on the upper-left) and Lisbon (on the lower-left).
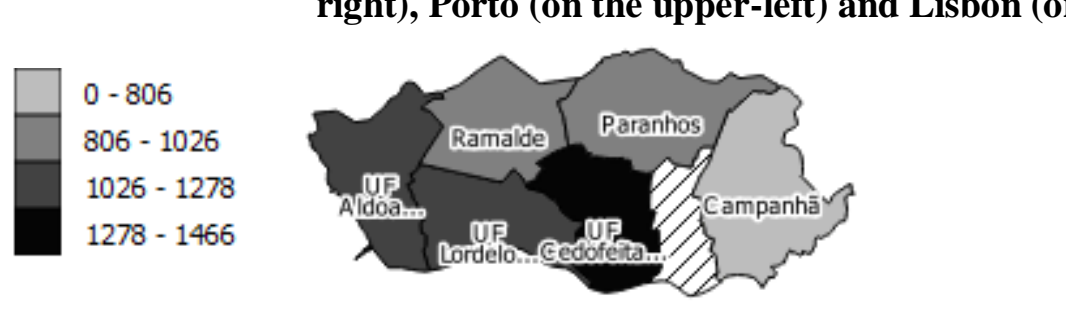

$0-1274$

$1274-1740$

$1740-2132$

$2132-2698$

$2698-3132$
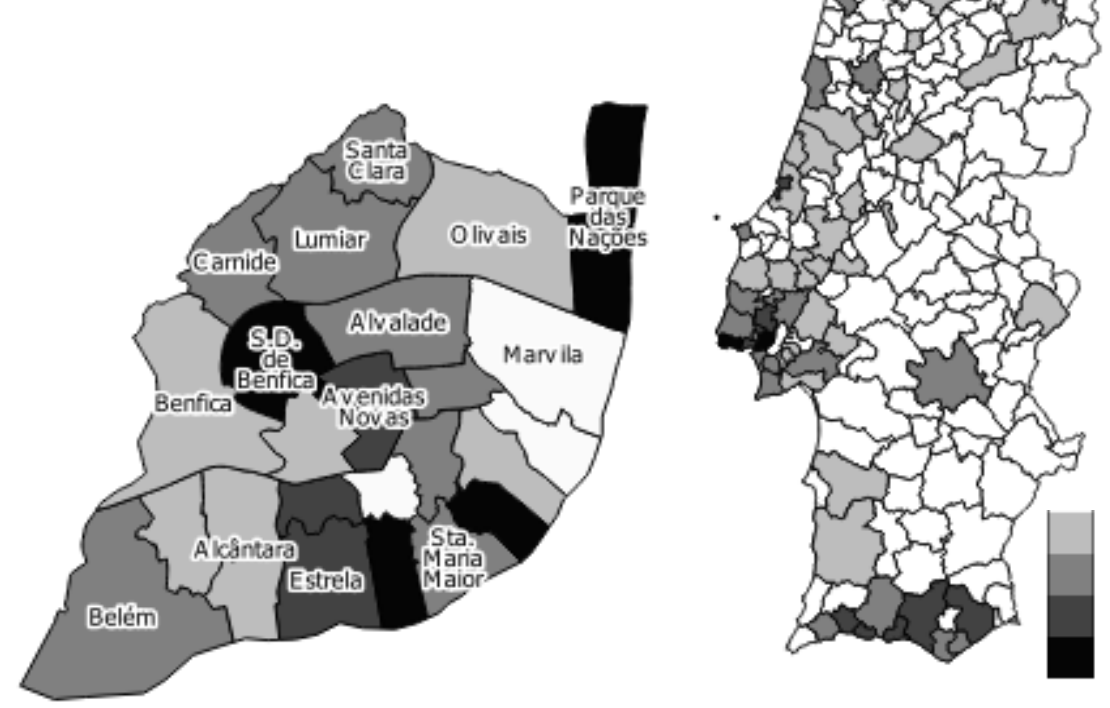

$0.0-769.8$ [42]

$769.8-1047.2[20]$

$1047.2-1502.7$ [11]

$1502.7-2187.8$ [2]

Finally, Figures 4 and 5 summarize our dataset and illustrate the regional differences in the value of rents and sales across municipalities in mainland Portugal and across civil parishes for Lisbon and Porto in the first quarter of 2015. Most of the regions covered in the dataset are coastal regions or district capitals, where $80 \%$ of the population in Portugal is concentrated. This is because that is where most housing transactions take place. The two maps present a similar pattern - housing costs, both in terms of rents and transaction prices, are highest in the cities of Lisbon (located in the costal central part of Portugal) and Porto (located in the Northern part of the country), and in the district of Faro located in the southern region of Algarve. Within the city of Lisbon housing costs are highest in the southern part, in the historic downtown 
area of Baixa; in Parque das Nações, a newly built area well-endowed with environmental amenities; and in São Domingos de Benfica and Avenidas Novas.

As for the city of Porto, prices are also highest in the historic center, the oldest area of the city classified as World Heritage by UNESCO since 1996 and comprising the civil parishes of Cedofeita, Santo Ildefonso, Sé, Miragaia, São Nicolau e Vitória.

Figure 5: Rental values $€$ per $\mathrm{m}^{2}$, in the $1^{\text {st }}$ quarter of 2015, in Mainland Portugal (on the right), Porto (on the upper-left) and Lisbon (on the lower-left).
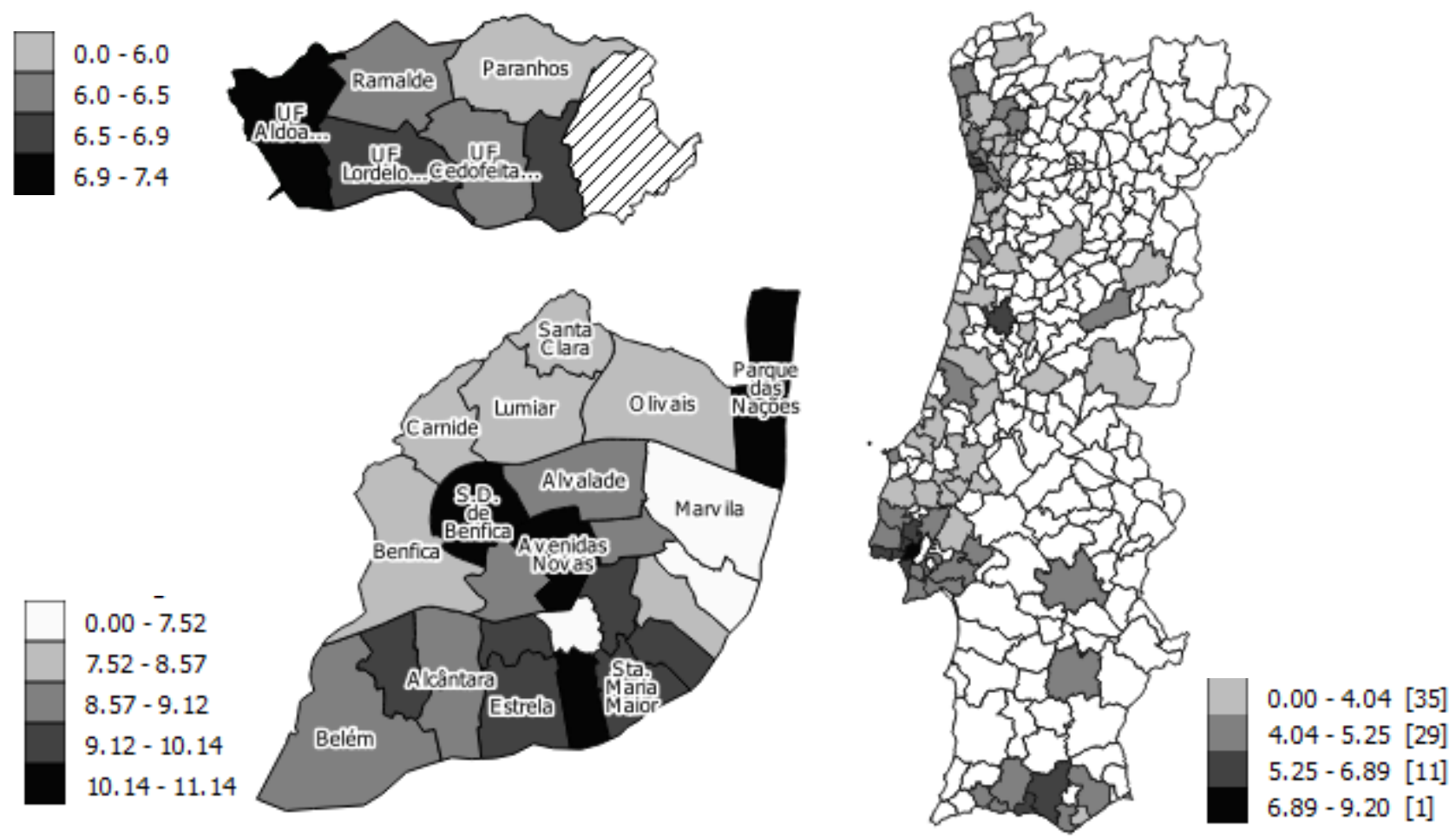

\subsection{Number of Short-term Rentals}

The supply of short-term rentals in Portugal is officially registered with the National Tourist Registry Registo Nacional de Alojamento Local (RNAL). The number of registers with the RNAL system increased substantially from 2014, with 1715 registers in 2013, 3386 in 2014 and 11218 in 2015. As of 2016, there were already 32622 short-term rentals registered in RNAL, 96\% of those located in mainland Portugal. Table 1 presents the share of short-term rentals in RNAL database by district, municipality and civil parish relative to total for 2016. From Table 1, the majority of short-term rentals registered in RNAL are concentrated in the districts of Faro, Lisbon and Porto which together account for $82 \%$ of all registries in 
this dataset in 2016. Similarly, the top five municipalities in mainland Portugal, all located in these three districts, account for nearly half of the hosts registries.

When looking at the distribution of Airbnb listings the statistics are slightly different. Table 2 presents the share of Airbnb listings by district, municipality and civil parish relative to total listings for 2016. As of 2016 there were almost 44411 listings in this home-stay site. When looking at the distribution of the hosts by districts, Lisbon, Faro and Porto still account for the majority of the local rental listings, representing $74 \%$ of the hosts' registries.

Table 1: Share of short-term rentals in RNAL by district, municipality and civil parish in 2016.

\section{DISTRICTS MUNICIPALITIES PARISHES}

\begin{tabular}{l|lll}
$\mathbf{1}$ & Faro $-49.3 \%$ & Lisbon (Lisbon) $-18.5 \%$ & Sta. Maria Maior (Lisbon) $-5.3 \%$ \\
$\mathbf{2}$ & Lisbon $-24.4 \%$ & Albufeira (Faro) $-9.6 \%$ & UF Cedofeita, ... (Porto) $-5.0 \%$ \\
$\mathbf{3}$ & Porto $-8.4 \%$ & Portimão (Faro) $-7.5 \%$ & Misericórdia (Lisbon) $-4.1 \%$ \\
$\mathbf{4}$ & Leiria $-4.7 \%$ & Porto (Porto) $-6.7 \%$ & Sto. António (Lisbon) $-1.8 \%$ \\
$\mathbf{5}$ & Setúbal $-2.9 \%$ & Lagos (Faro) $-6.6 \%$ & Arroios (Lisbon) $-1.7 \%$
\end{tabular}

Table 2: Share of Airbnb listings by district, municipality and civil parish in 2016.

\begin{tabular}{l|lll}
\multicolumn{2}{c}{ DISTRICTS } & MUNICIPALITIES & PARISHES \\
\hline $\mathbf{1}$ & Lisbon $-32.0 \%$ & Lisbon (Lisbon) $-21.3 \%$ & UF Cedofeita, ... (Porto) $-6.0 \%$ \\
$\mathbf{2}$ & Faro $-27.7 \%$ & Porto (Porto) $-9.4 \%$ & Sta. Maria Maior (Lisbon) $-5.5 \%$ \\
$\mathbf{3}$ & Porto $-12.9 \%$ & Albufeira (Faro) $-5.2 \%$ & Misericórdia (Lisbon) $-4.4 \%$ \\
$\mathbf{4}$ & Leiria $-5.5 \%$ & Loulé (Faro) $-4.1 \%$ & Albufeira (Faro) $-4.3 \%$ \\
$\mathbf{5}$ & Setúbal $-5.2 \%$ & Lagos (Faro) $-3.9 \%$ & Arroios (Lisbon) $-3.0 \%$
\end{tabular}

Figure 6 shows the number of new listings in the Airbnb site and in the RNAL database in the municipalities of Lisbon and Porto relative to the rest of the country from 2010 to 2016. Figure 7 illustrates the gap between the Airbnb listings for the municipalities of Lisbon and Porto and those observed in the RNAL site.

Both figures reveal that right after the policy reform DL128/2014 was published there was a substantial increase in the number of listings in both sites but particularly in the number of listings for the rest of mainland Portugal within the RNAL website. The simplification of the RNAL registration process introduced by the policy change seemed to have created an incentive for more hosts, in particular those located outside the most important cities in mainland Portugal, to start renting their homes and rooms to tourists. It is thus this heterogeneity in the geographic distribution of short-term rentals that allows us to 
estimate the causal effect of the 2014Q3 policy change on house and rental prices by allowing us to compare areas which were directly affected and areas that were not affected by the policy change.

Figure 3: Number of new listings in the Airbnb site and in the RNAL dataset for Lisbon and Porto and for the rest of the country.

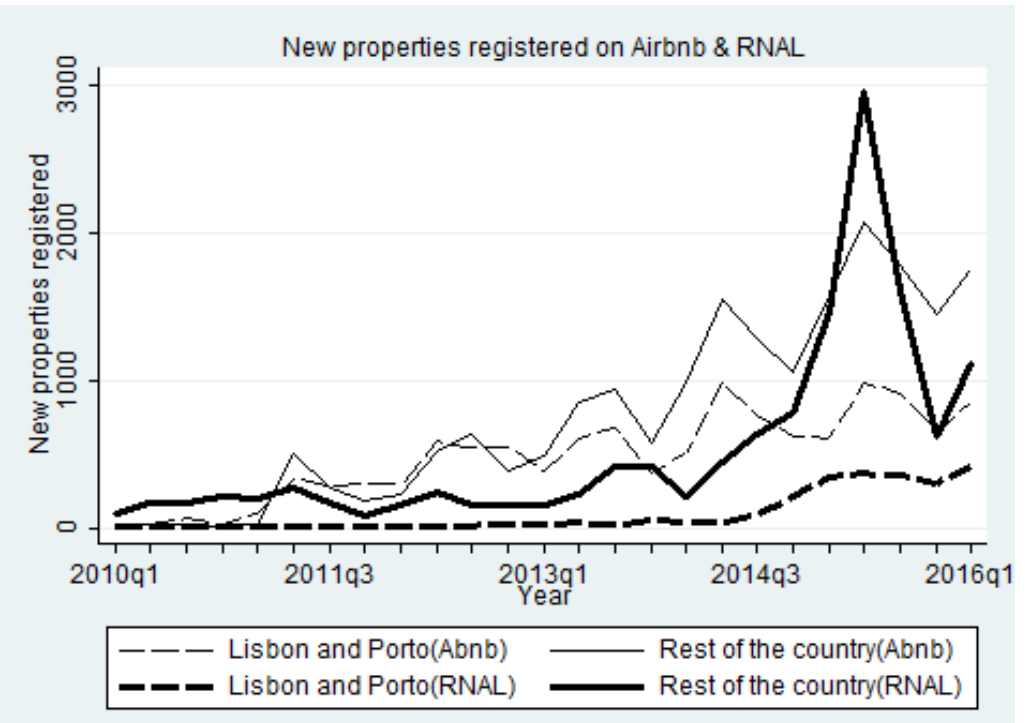

Figure 4: Difference from Lisbon and Porto to the rest of Portugal in the number of new listings in RNAL and Airbnb.

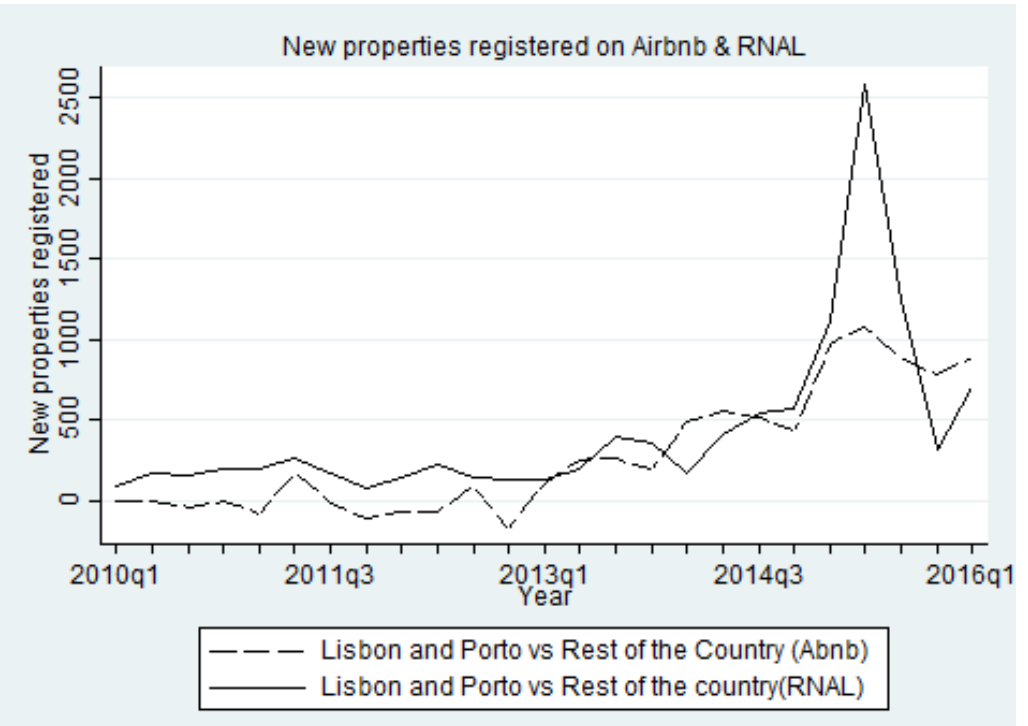




\section{Description of the Data}

We collect information on Airbnb listings data from web scrapes from the Airbnb website during the month of September 2016 for several municipalities in mainland Portugal. For every Airbnb listing we have the location of the listed property (address and georeferenced coordinates), the daily price, a range of characteristics of the listed property (e.g. number of rooms, number of bathrooms), the host id, the list of all reviews from guests who have stayed at the property and the year-month in which the user registered as a host on the platform. Our final Airbnb dataset contains 44411 Airbnb listings spanning a period of 7 years, from 2011 to 2016.

Average quarterly sale prices and housing rental prices from the $1^{\text {st }}$ quarter of 2011 to the $1^{\text {st }}$ quarter of 2016 for 137 municipalities in Portugal and for all the civil parishes in the municipalities of Porto and Lisbon are obtained from Confidencial Imobiliário. This company is a data bank, being the only source in Portugal with statistical data on transaction prices and residential lease agreements. The 137 municipalities included in our dataset represent $35 \%$ of the existing municipalities in Portugal, encompassing $80 \%$ of the population living in the country. The reason for not covering all the municipalities in the country is that in many of the smaller municipalities there are no regular housing transactions so that no sale residential price data can be collected. For the same reason, with the exception of Lisbon and Porto, rental and house prices were just available at the municipality level. For Lisbon and Porto those sale prices were also available at the civil parish level. As such, we calculate the level of Airbnb activity as the number of Airbnb listings either at the civil parish (just for Lisbon and Porto) or at the municipality levels using GIS techniques. We also calculate the number of listings in the Airbnb platform for each year using the reported entry date.

Our socio-demographic area characteristics, the total number of lodgings and population at both municipality and civil parish levels were obtained from the 2011 Census. We further gather census data for each of the civil parishes on the number of lodgings per use type (residential, seasonal, rental, and other), the building age, housing density, population density, monthly cost of housing, population age and the average number of floors per building.

Finally, it should be noted that in 2013 there was a reorganization of the administrative boundaries of the civil parishes in Portugal (Law 11-A/2013). This administrative reform required the reduction, the amalgamation or extinction of various civil parishes as an attempt to control spending in light of the 2012 country sovereign debt crisis. The reform affected particularly the municipalities of Lisbon and Porto, which before the year 2013 had 53 and 15 civil parishes, but only 24 and 7 after, respectively. Since our Census data is from 2011, we had to convert the old civil parishes into the new parish divisions.

Table A.1 in the Appendix provides the summary statistics for our sample. 


\section{Methodology}

Both Barron et al. (2018) and Sheppard and Udell (2018) present a simple theoretical model that explores the arguments that potentially justify an a priori view that Airbnb listings might have an impact on house prices. On the one hand, Airbnb provides homeowners with an increase in income which in turn results in an increase in their demand for residential space. Moreover, Airbnb also allows non-residents (e.g. tourists), who also demand living space, to occupy the city. Local incomes and population may further increase if Airbnb guests spend money nearby their Airbnb rentals. On the other hand, Airbnb guests can create negative externalities such as noise and congestion of publicly provided goods such as transportation. To the extent that these channels work on opposite directions on rent and property values, the theoretical net impact of Airbnb listings is ambiguous and provides motivation for an empirical investigation.

Our goal in this paper is therefore to quantify the causal effect of short-term rentals on house prices and rents. We first start with a simple regression analysis and then introduce an instrumental variable estimator. However, because this first approach can at best estimate associational relations, we also employ a $\mathrm{DiD}$ approach that examines how the DL128/2014 policy reform has affected housing prices and rents in Portugal.

Simple regression analysis will suffer from standard endogeneity problems since, for example, house prices/rents as well as touristic value are both determined by the amenities and the characteristics of an area (omitted variables). To account for such amenities and characteristics, our OLS results condition on the percentage of run-down houses, housing and population density, population age, average dwelling age, average number of floors, ageing dependency (ratio of the number of people over age 64 to the number of people aged 15-64), population renovation (ratio of people in the age of 20-29 to the number of people in the age 55-64) and population longevity (ratio of the number of people over age 74 to the number of people over 64). All variables are measured at the municipality level.

\section{Baseline OLS Specifications}

Let $Y_{\text {it }}$ denote either the natural log of average house price or the natural log of average rent in municipality $i$ in period $t$ (where a period is a given quarter-year), AbbDensity ${ }_{i t}$ is the share of properties on Airbnb to the total number of houses in municipality $i$ in period $t$ and Covariates $i$ denote a vector of timeinvariant amenities in municipality $i$. Finally, $\tau_{t}$ are year-quarter fixed effects and $\varepsilon_{i t}$ contains municipality level shocks to house prices or rents. Standard errors are clustered at the municipality level. In our baseline model our specification follows:

$$
Y_{i t}=\alpha_{0}+\alpha_{1} \text { AbbDensity } \text { it }+\alpha_{2} \text { Covariates }+\tau_{t}+\varepsilon_{i t} .
$$


We also report the results from a specification where we include municipality level fixed effects denoted by $\varepsilon_{i}$. Since all our covariates are time-invariant, in this specification their effects cannot be identified (multicollinearity). Hence in this case we obtain the following specification:

$$
Y_{i t}=\alpha_{0}+\alpha_{1} \text { AbbDensity }_{i t}+\tau_{t}+\varepsilon_{i}+\varepsilon_{i t}
$$

\section{Specification}

Our baseline OLS results can nevertheless still be biased due to endogeneity issues and due to unobserved municipality-specific, time-varying factors contained in our error term that are correlated with Airbnb density. To address this concern, we follow Barron et al. (2018) and instrument tourism pressure with Google trends for the word "Airbnb" $\left(\right.$ Ggltrends $\left._{t}\right)$ interacted with a measure of how "touristy" a municipality is in the base quarter-year $\left(A b b\right.$ Density $\left._{i, Q 1 Y 04}\right)$. We define "touristy" to be a measure of a municipality's attractiveness for tourists and proxy it using the share of Airbnb listings in the first quarter of 2014 (i.e. before the policy change). The policy was introduced in the third quarter of 2014. We use the first quarter of 2014 to avoid any anticipation effects of the policy so we avoid the second quarter. The fact that we use a pre-policy measure, it means that it is independent from any unexpected future shocks to local housing markets. Furthermore, the inclusion of municipality level fixed effects controls for the ex-ante sources of heterogeneity (omitted variables). This instrument is expected to explain the variation of shortterm rentals because areas that had a stronger presence of Airbnb before the policy are more likely to experience a growth of Airbnb over time as Airbnb becomes more in demand and property owners become more aware of the benefits of short-term rentals. Since the presence of Airbnb in the first quarter of 2014 may signal how touristy a given municipality is, we test the instrument significance in the first stage regression. Moreover, the exposure of "high" versus "low" touristy municipalities to Airbnb over time is expected to have no direct effect on the housing market and is thus uncorrelated with house prices. The intuition for this second assumption rests on the exogeneity of the aggregated trend in Airbnb Google searches to local shocks on house prices. The necessary exclusion restriction that guarantees identification is then that the evaluation of Airbnb Google searches in high versus low touristy areas only affect house prices through its effects on the demand from tourism (share of Airbnb listings).

The specification we use for the IV strategy is the following. In the first stage we predict Airbnb density in municipality $i$ and time $t$ as a function of Airbnb awareness (measured using Google trends) interacted with our "touristiness" measure that proxies how attractive a municipality is for tourists in the first quarter of the base year of 2014:

$$
\text { AbbDensity }_{i t}=\beta_{0}+\beta_{1} \text { AbbDensity }{ }_{i, Q 1 Y 04} * \text { Ggltrends }_{t}+\gamma_{t}+\epsilon_{i}+\epsilon_{i t} .
$$


The second stage of our analysis computes the log of house prices or rental prices as a function of the predicted Airbnb density and all the same controls used in the first stage:

$$
Y_{i t}=\alpha_{0}+\alpha_{1} A b b \overline{\overline{D e n}} s i t y_{i t}+\tau_{t}+\varepsilon_{i}+\varepsilon_{i t}
$$

However, the IV condition may be violated, and its validity is untestable (Barron et al. 2018). For the instrument to be valid it must be the case that it is uncorrelated with municipality-specific, time-varying shocks to the housing market, for instance gentrification. This requires that either ex-ante "touristiness" in 2014 be independent of future municipality level shocks, or growth in Airbnb searches be independent of municipality-level shocks. Now suppose that there is a long-run trend towards gentrification, which leads to higher house prices over time. In addition, this gentrification trend is higher in more touristy areas. Since there is also a systematic long-run trend in the time-series variable (Google trends), the instrument may no longer be independent from the error term. In this case our 2SLS estimates may reflect the effects of gentrification rather than home-sharing. While exogeneity of ex-ante "touristiness" to future shocks to the housing market are a plausible assumption, it is the differential growth of Airbnb online searches that is a potential source of concern. Therefore, we compare the IV estimates to our preferred method which uses a DiD estimator. This estimator exploits the policy change by comparing the evolution of house prices and rents in municipalities with high versus low presence of Airbnb. In addition to this binary measure of tourism, we also use the continuous measure of Airbnb density previously defined as the share of Airbnbs in the first quarter of 2014 (before the policy introduction).

\section{Difference-in-Differences}

To construct the $\mathrm{DiD}$ estimator we rely on the 2014 policy change which reduced the barriers to entry in the short-term rental market. As seen in section 4.3, registrations in RNAL spiked in the third quarter of 2014, after the publication of the policy DL128/2014. The policy is not expected to have any effects in municipalities without tourism (control group) since these municipalities have low potential for Airbnb development. On the other hand, we hypothesize that the policy may have effects in the touristy municipalities since in these municipalities the liberalization will allow the Airbnb presence to increase and thus put upward pressure on house prices and rents. Summarizing, the only way the policy can affect house prices, is through its effect on Airbnb presence. The control group is thus composed by municipalities that have little to none ex-ante Airbnb listings (proxy for the "touristiness" of the municipality) and therefore not directly affected by the policy change while the treatment group is composed by municipalities with larger ex-ante Airbnb presence. 
Table 3 ranks the top 6 municipalities by Airbnb presence (Table A. 2 contains in the Appendix contains the ranking of the top 20 municipalities by Airbnb presence). The treatment group is then defined by these municipalities which have the largest Airbnb presence: Sta Maria Maior, Misericordia, Sto. Antonio, UF Cedofeita, S. Vicente, and Arroios. As a robustness check we expand this set of municipalities to also include the second set of municipalities by Airbnb presence: Bonfim, Peniche, Avenidas Novas (Lisboa), Mafra, Cascais, Penha de França (Lisboa), Grandola, Campolide (Lisboa), and Alvalade (Lisboa) as reported in Table A.2. We exclude nevertheless from the list, the municipalities in Portugal's southernmost region of Algarve which we use as a placebo group (see Table A.2 for the construction of the treatment, treatment extended and placebo groups). The reason to exclude the municipalities in Algarve is because Algarve is the main beach and golf destination in Portugal and short-term rentals have been a strong presence in the region long before the existence of Airbnb and other similar short-term rentals platforms.

We also report in Table A.2 the density of properties in the national registry (RNAL). The numbers confirm that the Algarve has a strong presence of short-term holiday homes although many are not present in Airbnb. For example, for the most popular municipality in the Algarve region, Albufeira, the density of Airbnb houses is $1.76 \%$ while the density of houses in the national registry is $2.91 \%$. Therefore given that short-term rentals existed in the Algarve long before the existence of Airbnb, we do not expect to find an impact of the policy on house and rental prices in this region.

Table 3: Density of short-term rentals (share of the number of houses in the municipality) - data for the $1^{\text {st }}$ quarters of 2014 and 2016.

\begin{tabular}{l|ll} 
& \multicolumn{1}{c}{$\mathbf{1}^{\text {ST }}$ QUARTER - 2014 } & \multicolumn{1}{c}{$\mathbf{3}^{\text {RD }}$ QUARTER - 2016 } \\
\hline $\mathbf{1}$ & Sta. Maria Maior (Lisbon) $-13.0 \%$ & Sta. Maria Maior (Lisbon) $-22.6 \%$ \\
$\mathbf{2}$ & Misericórdia (Lisbon) $-11.3 \%$ & Misericórdia (Lisbon) $-17.5 \%$ \\
$\mathbf{3}$ & Sto. António (Lisbon) $-5.4 \%$ & Sto. António (Lisbon) $-10.3 \%$ \\
$\mathbf{4}$ & UF Cedofeita, ... (Porto) $-4.0 \%$ & UF Cedofeita, ... (Porto) $-8.8 \%$ \\
$\mathbf{5}$ & S. Vicente (Lisbon) $-3.9 \%$ & S. Vicente (Lisbon) $-7.9 \%$ \\
$\mathbf{6}$ & Arroios (Lisbon) $-2.6 \%$ & Arroios (Lisbon) $-5.3 \%$
\end{tabular}

We implement our $\mathrm{DiD}$ model as an interaction term between time and treatment group dummy variables in the regression model:

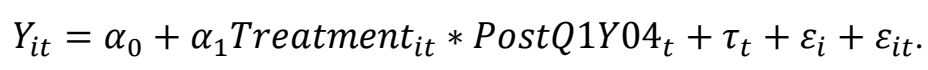

A valid DiD for causal inference rests nevertheless on the stable unit treatment value assumption (SUTVA). SUTVA requires that the response of a particular unit should be unaffected by the particular assignment of treatments to the other units. Yet, this may prove difficult in urban settings because high treatment areas may affect contiguous low treatment areas through equilibrium effects (Rubin (2005), 
Baum-Snow and Ferreira (2014)). One way to overcome this problem is to aggregate the data to the highest possible unit. In our analyses our unit of observation is either the municipality or the civil parish. It should be noted that within the context of our analyses, violation of the SUTVA would actually decrease the treatment effect from short-term rentals, as a strong treatment would increase not only the house price in its municipality but also in other municipalities, reducing the gap between the two. As such, in the case of a violation of SUTVA, the estimated treatment effect generated by the Airbnb becomes a lower bound and our results are a conservative estimate of the true effect.

\section{Results}

\subsection{Is there empirical evidence that Airbnb has pushed house prices and rents up?}

The main results of our two empirical approaches are displayed in Tables 4 and 5.

\section{Simple OLS and IV Evidence}

Table 4-columns (1)-(4) report the simple OLS results of the log of house prices on the share of Airbnb listings in a given municipality, that is, density. The coefficient on density in Table 4- column (1), shows that without controls, moving from a municipality with no Airbnb listings to a municipality with a $10 \%$ share of Airbnbs results in a $77.8 \%$ increase in house prices. Once we include controls for municipality amenities and characteristics this estimate drops, a 10p.p. increase in the share of Airbnb listings in a municipality is associated with just a $46.3 \%$ increase in house prices (see Table 4- column (2)). ${ }^{11}$ We should note that these controls are time-invariant and do not account for other unobserved characteristics. In both cases, the other variables always have the expected signs and most are statistically significant. In Table 4column (3) we introduce municipality fixed effects and the estimated coefficient is further reduced from $46 \%$ to $36 \%$.

Table 4-column (4) reports the 2SLS results using the instrumental variable with both municipality level and time fixed effects (and without the time invariant controls that are collinear with municipality fixed effects). The diagnostics show a very significant first stage (p-value<0.001) meaning that our instrument is relevant and a non-rejection of the exogeneity of the FE model of column (3) (p-value=0.362). Regarding our variable of interest, the IV results show only a small reduction of our previous estimate with the simple OLS-FE model. A 10p.p. increase in the share of Airbnb listings in a municipality is now associated with a $34.9 \%$ increase in house prices.

\footnotetext{
${ }^{11}$ We should note that only two of our sample municipalities have more than $10 \%$ of properties on Airbnb - Santa Maria Maior and Misericordia and only five municipalities have a concentration above 5\% - Arroios, Lagos, São Vicente, Santo António, and UF Cedofeita.
} 
Table 4-columns (5)-(8) repeat the regressions when the dependent variable is the logarithm of rent values. As with the house price regressions, we find that controlling for municipality amenities and characteristics is important, as the estimated effect of Airbnb listings increases substantially when controls are excluded. Further, it is worth noting, that as in the case of house prices, in the rent regression the 2SLS estimate (column (8)) and the FE estimate with municipality fixed effects (Column (7)) have very different magnitudes. Finally, for rents we reject the validity of the OLS-FE model (p-value=0.01). This suggests that omitted factors such as gentrification may be positively correlated with Airbnb listings for the case of rents, thus creating a positive bias.

Table 4: OLS and IV estimates of the effect of the concentration of Airbnb listings in a municipality on average home sale prices and average rents.

\begin{tabular}{|c|c|c|c|c|c|c|c|c|}
\hline & (1) & $(2)$ & (3) & (4) & (5) & $(6)$ & $(7)$ & $(8)$ \\
\hline Method: & OLS & OLS & FE & IV & OLS & OLS & FE & IV \\
\hline Dep. Variable: & \multicolumn{4}{|c|}{$\log ($ sales $)$} & \multicolumn{4}{|c|}{$\log$ (rents) } \\
\hline Airbnb density & $\begin{array}{c}7.783 \text { *** } \\
(1.215)\end{array}$ & $\begin{array}{c}4.633 * * * \\
(1.019)\end{array}$ & $\begin{array}{c}3.625 * * * \\
(0.416)\end{array}$ & $\begin{array}{c}3.491 * * * \\
(0.417)\end{array}$ & $\begin{array}{c}6.050 * * * \\
(0.981)\end{array}$ & $\begin{array}{l}1.473 * * \\
(0.707)\end{array}$ & $\begin{array}{c}0.436 * * \\
(0.191)\end{array}$ & $\begin{array}{c}0.379 * * \\
(0.191)\end{array}$ \\
\hline Observations & 1,213 & 1,213 & 1,213 & 1,213 & 1,356 & 1,356 & 1,356 & 1,356 \\
\hline $\begin{array}{l}\mathrm{R}^{2} \text {-adjusted } \\
\text { IV first stage } \\
\text { (pval) } \\
\text { Endogeneity } \\
\text { (pval) }\end{array}$ & 0.175 & 0.806 & 0.920 & $\begin{array}{l}0.920 \\
0.000\end{array}$ & 0.165 & 0.895 & 0.955 & $\begin{array}{l}0.955 \\
0.000\end{array}$ \\
\hline Quarter-year FE & Yes & Yes & Yes & Yes & Yes & Yes & Yes & Yes \\
\hline Municipality FE & No & No & Yes & Yes & No & No & Yes & Yes \\
\hline Covariates & No & Yes & No & No & No & Yes & No & No \\
\hline
\end{tabular}

Significance levels: $* * * \mathrm{p}<0.01, * * \mathrm{p}<0.05, * \mathrm{p}<0.1$.

Notes: Standard errors in parentheses clustered at the municipality level. Simple OLS results reported in columns (1) and (5) and with municipality level covariates in columns (2) and (6). Columns (3) and (7) introduce fixed effects at the municipality level. The instrument in columns (4) and (8) is the interaction of Google time trends for the word "Airbnb" times the share of properties on Airbnb in the first quarter of 2014 (before the policy).

\section{Causal Effects by Difference-in-Differences: Mainland Portugal}

The results presented before cannot be given a clear causal interpretation. In particular, the Airbnb measure is time varying and may be correlated with other unobserved time-varying factors such as gentrification. The problem may be mitigated with the use of the instrument but we have no way of testing its validity. Furthermore, there might be an upward or a downward bias to the estimated effects given the nature of Airbnb density growth. To properly evaluate the causal impact of Airbnb listings on house prices and rents, we instead rely on a quasi-experimental design that uses a difference-in-differences technique. We estimate the effect of a specific intervention in the short-rental market (enactment of policy DL128/2014) by comparing the changes in house prices and rents over time between properties that are 
located in high-Airbnb awareness (the treatment group) and low-Airbnb awareness. We implement our DiD model as an interaction term between time and treatment group dummy variables in the regression model as explained in section 4. Table 5 presents our DiD results. We also perform several robustness checks by varying the definition of the treatment group and by constructing a placebo group. The placebo group in our case are areas that have large presence of short-term rentals but that already existed before the entry of Airbnb - the municipalities in the Algarve region. All our regressions include the controls described in the previous section and year-quarter and municipality fixed effects.

\section{Table 5: DiD estimates of the effect of the concentration of Airbnb listings in a municipality on} average home sale prices and average rents.

\begin{tabular}{lcc}
\hline & $(1)$ & $(5)$ \\
Dep. Variable & $\log (\mathrm{sales})$ & $\log (\mathrm{rents})$ \\
\hline Treatment (dummy) & $0.818^{* * *}$ & $0.902 * * *$ \\
& $(0.0210)$ & $(0.00777)$ \\
Treatment x 2014 & 0.135 & -0.0137 \\
& $(0.0813)$ & $(0.0214)$ \\
Treatment x 2015 & $0.260 * * *$ & $0.0413^{*}$ \\
& $(0.0502)$ & $(0.0220)$ \\
Treatment x 2016 & $0.340 * * *$ & $0.109 * *$ \\
& $(0.0652)$ & $(0.0427)$ \\
\hline Observations & 1,213 & 1,356 \\
$\mathrm{R}^{2}$-adjusted & 1.000 & 0.998 \\
Quarter-year FE & Yes & Yes \\
Municipality FE & Yes & Yes \\
\hline \hline
\end{tabular}

From Table 5 we see that house prices in the treated municipalities have increased by $34.0 \%$ in 2016 compared to prices in the control municipalities. Rents also increased by $10.9 \%$. These percentages are directly comparable to our previous regression results. For the comparison we need to multiply the estimated effects from Table 4 with the average Airbnb density in the treatment group, which is $11.2 \%$ for the first quarter of 2016. We should remind the reader that in Table 4 the explanatory variable was the contemporaneous Airbnb density in municipality $i$ and period $t$ while in the DiD the explanatory variable is the density of Airbnb in the $1^{\text {st }}$ quarter of 2014. The values are thus substantially different given that Airbnb presence was growing over the period. As such, the average estimates from columns (2) and (6) of Table 4 give us an estimated increase of $51.8 \%(=4.63 * 0.112)$ for house prices and $16.5 \%(=1.47 * 0.112)$ for rents while using the estimates from columns (3) and (7) we obtain an estimated effect of $40.6 \%(=3.63 * 0.112)$ 
for house prices and $4.9 \%(=0.436 * 0.112)$ for rents. These numbers compare with our DiD estimate of $34.0 \%$ for house prices and $10.9 \%$ for rents.

\subsection{Robustness Checks}

To evaluate the robustness of our previous results we start by extending the set of treated municipalities to make sure our results are not a mere statistical occurrence due to our definition of high and low Airbnb presence. Second, we want to make sure our results are not due to differences in house prices evolution between urban and non-urban areas so we restrict our set of municipalities to the urban areas of Lisbon and Porto. Third, we perform a placebo test on similar municipalities (by presence of Airbnb) but where the effect of Airbnb on house prices should not be present. In the final robustness exercise we use a continuous treatment variable instead of the binary definition. This way we have a varying level of treatment across municipality depending on the presence of Airbnb (Airbnb density).

Table 6: Robustness checks: DiD estimates of the effect of the concentration of Airbnb listings in a municipality on average home sale prices and average rents.

(1) (2) (3) - (4)

\begin{tabular}{|c|c|c|c|c|c|c|c|c|}
\hline \multirow[b]{2}{*}{ Dep. Variable } & (1) & (2) & (3) & (4) & (5) & (6) & (7) & (8) \\
\hline & & $\log$ (sales) & & & \multicolumn{4}{|c|}{$\log$ (rents) } \\
\hline \multirow{2}{*}{$\begin{array}{l}\text { Treatment } \\
\text { (dummy) }\end{array}$} & $0.818 * * *$ & $0.836^{* * *}$ & $-0.0626 * * *$ & $0.351 * * *$ & $0.902 * * *$ & $0.814 * * *$ & $0.0810 * * *$ & $0.328 * * *$ \\
\hline & $(0.0210)$ & $(0.0189)$ & $(0.0211)$ & $(0.0113)$ & $(0.00777)$ & $(0.00634)$ & $(0.00708)$ & $(0.00835)$ \\
\hline \multirow[t]{2}{*}{ Treatment x 2014} & 0.135 & 0.0719 & 0.111 & -0.0451 & -0.0137 & 0.0133 & -0.0150 & $-0.0348 * *$ \\
\hline & $(0.0813)$ & $(0.0497)$ & $(0.0807)$ & $(0.0308)$ & $(0.0214)$ & $(0.0149)$ & $(0.0228)$ & $(0.0150)$ \\
\hline \multirow[t]{2}{*}{ Treatment x 2015} & $0.260 * * *$ & $0.155^{* * *}$ & $0.225 * * *$ & 0.00430 & $0.0413 *$ & $0.0348 * *$ & 0.0155 & -0.0126 \\
\hline & $(0.0502)$ & $(0.0483)$ & $(0.0517)$ & $(0.0283)$ & $(0.0220)$ & $(0.0156)$ & $(0.0227)$ & (0.0198) \\
\hline \multirow[t]{2}{*}{ Treatment x 2016} & $0.340 * * *$ & $0.212 * * *$ & $0.308 * * *$ & 0.0444 & $0.109^{* *}$ & $0.0990 * * *$ & 0.0588 & -0.0575 \\
\hline & $(0.0652)$ & $(0.0563)$ & $(0.0686)$ & $(0.0332)$ & $(0.0427)$ & $(0.0341)$ & $(0.0437)$ & $(0.0391)$ \\
\hline Observations & 1,213 & 1,213 & 507 & 1,112 & 1,356 & 1,356 & 557 & 1,255 \\
\hline $\mathrm{R}^{2}$-adjusted & 1.000 & 1.000 & 1.000 & 1.000 & 0.998 & 0.998 & 0.999 & 0.998 \\
\hline Quarter-year FE & Yes & Yes & Yes & Yes & Yes & Yes & Yes & Yes \\
\hline Municipality FE & Yes & Yes & Yes & Yes & Yes & Yes & Yes & Yes \\
\hline
\end{tabular}

\section{Causal Effects by Difference-in-Differences: Extended set of treated Municipalities}

Table 6 presents our Robustness checks. The first robustness check extends the definition of the treatment and control groups. In this specification, we further include in our treatment group the municipalities of Bonfim, Peniche, Avenidas Novas (Lisboa), Mafra, Cascais, Penha de França (Lisboa), Grandola, Campolide (Lisboa), and Alvalade (Lisboa). As explained above, these are the second set of 
municipalities ranked by density of Airbnb presence (see the rankings in Table A.2). As reported in column (2) of Table 6, the average effect on sales is reduced to $21.2 \%$. This is expected since the average density is now $5.7 \%$ which is half of the previous $11.1 \%$ and so the coefficient is thus roughly reduced by slightly more than half, consistent with a linear effect of the density of Airbnb listings on house prices. On the other hand, reported in columns (6) of Table 6, the effect on rental prices remains similar at 9.9\%, which suggests a non-linear effect of Airbnb density for the rental markets.

\section{Causal Effects by Difference-in-Differences: High population density areas only}

The fact that the treated municipalities are mostly urban and the control municipalities are mostly nonurban can potentially undermine our findings since other factors may explain the differential evolution of house prices in the urban vs non-urban areas. To exclude municipality differences as an explanatory reason for our findings we obtain a comparable set of municipalities for the treatment and control groups and restrict analysis to this subset of municipalities. To operationalize this comparison we restrict analysis to the urban municipalities that exhibit the largest house density in the country. To obtain this set of homogenous treatment and control groups, we select the subset of municipalities and civil parishes with a house density above 1,500 per squared $\mathrm{km}$. This results in a treatment and control group that includes all the civil parishes of Lisbon and Porto together with two suburban municipalities of Lisbon - Amadora and Odivelas. The results in columns (3) and (7) of Table 6 show that the effect on house prices remains similar at 30.8\%. This implies that our results are not driven by differences between urban and non-urban areas. Even within urban areas there is a distinct evolution of house prices between high and low Airbnb municipalities. The effect on rental prices is reduced to $5.9 \%$ and becomes statistically insignificant, possibly due to the much smaller sample sizes.

\section{Causal Effects by Difference-in-Differences: Placebo tests}

The placebo tests involve constructing a placebo group. In the placebo group the effect should not be present and finding it would suggest a misspecified design. As a placebo group we select a set of municipalities similar to the treated group but where the impact of Airbnb should not be present. Given the large tradition of the Algarve region as a beach destination with many holiday homes available for rental, it is also a region with large presence on Airbnb (see Table A.2). However, we make a distinction between the traditional markets for holiday homes, such as beach destinations, and the recent trend in short-term rentals potentiated by Airbnb. Short-term rentals are mostly an urban phenomenon, unlike beach holiday homes. Beach destinations have had for a long time an organized market for rental of these properties and the housing market is thus not expected to be strongly affected by the "new" online platforms such as Airbnb. This is because it is not expected to generate an increase in demand for short-term rentals in these 
areas, since they have already such a market in place. Airbnb is thus not expected to have an effect on house prices for these areas. It is similar to the treated group by the large presence of Airbnb and short-term rentals but we do not expect an impact of Airbnb presence on house prices because these short-term rentals already existed before the entry of Airbnb into the market. Finally, we exclude the baseline treatment group from the analysis to avoid contamination of the control group. The results in columns (4) and (8) of Table 6 show that we find no effect of Airbnb in the placebo groups. We thus have no evidence of design misspecification for our baseline results

\section{Table 7:- Differences-in-differences estimates for the effect of the concentration of short-term rentals on average prices.}

\begin{tabular}{|c|c|c|c|c|c|c|}
\hline & (1) & (2) & (3) & (4) & (5) & (6) \\
\hline Dep. Variable & \multicolumn{3}{|c|}{$\log ($ sales $)$} & \multicolumn{3}{|c|}{$\log$ (rents) } \\
\hline Airbnb Density x 2014 & $\begin{array}{c}1.295 \\
(0.984)\end{array}$ & $\begin{array}{c}0.937 \\
(0.943)\end{array}$ & $\begin{array}{c}1.530 \\
(2.372)\end{array}$ & $\begin{array}{l}-0.180 \\
(0.339)\end{array}$ & $\begin{array}{c}-0.241 \\
(0.377)\end{array}$ & $\begin{array}{c}0.655 \\
(2.151)\end{array}$ \\
\hline AirbnbDensity x 2015 & $\begin{array}{c}3.684 * * * \\
(0.797)\end{array}$ & $\begin{array}{c}3.078 * * * \\
(0.717)\end{array}$ & $\begin{array}{c}5.793 * * \\
(2.250)\end{array}$ & $\begin{array}{c}0.303 \\
(0.310)\end{array}$ & $\begin{array}{c}-0.0977 \\
(0.252)\end{array}$ & $\begin{array}{l}-0.158 \\
(2.069)\end{array}$ \\
\hline AirbnbDensity x 2016 & $\begin{array}{c}4.500 * * * \\
(0.959) \\
\end{array}$ & $\begin{array}{c}4.023 * * * \\
(0.947) \\
\end{array}$ & $\begin{array}{c}2.329 \\
(4.006) \\
\end{array}$ & $\begin{array}{c}2.264 * * * \\
(0.457)\end{array}$ & $\begin{array}{c}1.282 * * \\
(0.520) \\
\end{array}$ & $\begin{array}{r}5.755 \\
(7.735) \\
\end{array}$ \\
\hline Observations & 1,213 & 456 & 757 & 1,356 & 506 & 850 \\
\hline $\mathrm{R}^{2}$ & 1.000 & 1.000 & 1.000 & 0.998 & 0.999 & 0.998 \\
\hline Quarter-year FE & Yes & Yes & Yes & Yes & Yes & Yes \\
\hline Municipality FE & Yes & Yes & Yes & Yes & Yes & Yes \\
\hline
\end{tabular}

Significance levels: $* * * \mathrm{p}<0.01, * * \mathrm{p}<0.05, * \mathrm{p}<0.1$

Notes: Airbnb Density is defined as the number of properties on Airbnb in the first quarter of 2014 divided number of lodgings in the region. Columns (2) and (5) restrict to the parishes in Lisbon and Porto, while columns (3) and (6) only use the municipalities outside Lisbon and Porto. Standard errors clustered at the municipality level.

\section{Causal Effects by Difference-in-Differences: Continuous treatment effect (Airbnb density)}

Finally, we use also the continuous treatment metric (share of Airbnb to the total number of lodgings) in the first quarter of 2014 interacted with the post 2014 dummy. Table 7 reports larger estimated coefficients. For example, a municipality with an Airbnb density of $10 \%$ is expected to experience an increase in prices of $45.0 \%$ when compared to a municipality without the presence of local accommodation. The effect is $22.6 \%$ for rents. However, we must quantify these effects at the level of the density as defined in the first quarter of 2014. In this period the maximal density was $11.7 \%$ (instead of $20.7 \%$ by the end of 2016) and the average density for the municipalities placed in the treatment group was $5.9 \%$ (instead of $11.2 \%$ by the end of 2016). So we get larger estimated coefficients while the corrected estimated effects are of $52.6 \%$ on prices $(=4.50 * 0.117)$ and $13.4 \%$ on rents $(=2.26 * 0.059)$. Columns $(2)$ and (5) report the results for the municipalities of Lisbon and Porto only, with similar results for house prices and a reduction to half the effect for rental prices. In columns (3) and (6) we report the results just for the rest of the country, 
excluding Lisbon and Porto. Both effects become statistically insignificant outside the two main cities. This is consistent with the presence of local accommodation in urban centers. It is in the main and most important urban centers where we can find the largest increases in house prices.

\section{Conclusions}

Since it was founded in 2008, the short-term rental platform Airbnb has been the subject of critics that have blamed it for raising housing prices, changing employment dynamics and the quality of life of residential neighborhoods, and triggering gentrification and displacement of residents from central and urban historic zones. However, causal evidence on how Airbnb and other home-sharing platforms affect housing markets is mostly lacking, despite several cities worldwide have already reacted to the rise of Airbnb with different policy interventions, varying from laissez faire to prohibition to allowing it with certain restrictions.

This paper quantified the effect of an increase in the concentration of short-term rentals on house prices and rents. We focus our analysis in Portugal, taking advantage of a policy reform that took place in 2014 and which has liberalized the rental housing market for the entire country by facilitating the registration and set up of informal short-term rental businesses. Using a difference-in-differences empirical strategy we show that there was a $34 \%$ increase in property values and a $10.9 \%$ increase in rents between the introduction of the policy DL128/2014 until 2016 for areas with strongest presence of Airbnb. The numbers can be translated also into the effect of Airbnb density. As such, a 1 p.p. increase in the share of Airbnb properties translates into a $4.5 \%$ increase in house prices and a $2.26 \%$ increase in rent values. The effects are mostly localized to the historical sites of the two largest cities in Portugal, Lisbon and Porto, particularly in their historical centers, which exhibit levels of concentration of short-term rentals above the average. This may be due not only to geographical constraints but also to specific preferences by tourists who create extra demand pressure on these locations.

These effects are also not trivial, implying that even within historical centers large discrepancies have arisen solely due to the higher presence of short-term rentals. This should not be ignored, as these effects are far from neutral from a distributional point of view (see for example Koster et al. 2019). It can also lead to long-term impact in the historical centers, as locals move elsewhere. Despite the distributional concerns and the potential displacement of existing residents, this increase in house prices has also created incentives for dwellings in historical centers to be renovated and redeveloped. This process in turn has helped rebirth some of these old areas of the city by attracting younger population to invest and move in and through a gentrification process that has attracted people with higher incomes and also more upscale urban amenities and services. The study of these consequences should be the subject of future research. 
Finally, it should be noted that Lisbon and Porto have already introduced tourist taxes in 2016 and 2018, respectively, to help cope with increased pressures. The Algarve region also voted to follow suit in March 2018 (yet to be implemented). Moreover, these cities are currently weighting the benefits of expanding tourism accommodation at the expense of domestic housing, upmarket condominiums rather than affordable homes. ${ }^{12}$ In addition, as of July $1^{\text {st }} 2017$ accommodation rental websites such as Airbnb risk fines up to $€ 32,500$ if they run ads for properties in Portugal without displaying AL registration numbers. The AL registration number is the vacation home's identification number and signs that the offering is fully compliant with vacation rental laws and thus can be opened for business. The new decree law covers both the website and the property owner or promoter and a scale of fines has been published. ${ }^{13}$ The idea of this new rule is to reinforce the message that the registration of short-term rentals or Alojamento Local is mandatory by pushing illegal rentals off accommodation websites.

\section{References}

Albouy, David, Gabriel Ehrlich, and Yingyi Liu. 2016. "Housing Demand, Cost-of-Living Inequality, and the Affordability Crisis." National Bureau of Economic Research (NBER) Working Paper no. 22816, November 2016.

Barron, K., Kung, E., and Proserpio, D. 2018. "The Sharing Economy and Housing Affordability: Evidence from Airbnb". Working Paper.

Cocola-Gant A, 2016, "Holiday Rentals: The New Gentrification Battlefront". Sociological Research Online 21(3): 1-10.

Edelman, Benjamin, Michael Luca, and Dan Svirsky, "Racial discrimination in the sharing economy: Evidence from a field experiment," American Economic Journal: Applied Economics, 2017, 9 (2), 1-22.

Franco, Sofia F. and Jacob L. Macdonald, 2018, "Measurement and Valuation of Urban Greenness: Remote Sensing and Hedonic Applications to Lisbon, Portugal", Regional Science and Urban Economics, 72, 156180.

Franco, Sofia F. and Jacob L. Macdonald, 2018, "The Effects of Cultural Heritage on Property Values: Evidence from Lisbon, Portugal”, Regional Science and Urban Economics, 70, 35-56.

\footnotetext{
${ }^{12}$ A March 2017 article published in the Property section of the Financial Times reports that Graça, a hilltop neighborhood in the historic heart of Lisbon, is currently undergoing a process of urban construction, demolition and restoration. Old buildings are being made into luxury apartment blocks and dilapidated mansions converted into smart hotels.

${ }^{13}$ The fines for property owners are between $€ 125$ and $€ 3,250$ for individuals and between $€ 1,250$ and $€ 32,500$ if the owner is a company. Fines for the hosting websites are the same with sites owned by companies attracting fines of between $€ 1,250$ and $€ 32,500$ and sites owned by individuals receiving fines of between $€ 125$ and $€ 3,250$.
} 
Gottlieb , C. 2013. "Residential short-term rentals: Should local governments regulate the "industry"? Planning and Environmental Law, 65 ( 2 ), 4 - 9.

Gurran, N., and Phibbs, P. 2017. "When tourists move in: How should urban planners respond to Airbnb?" Journal of the American Planning Association, 83(1), 80-92.

Guttentag, D. 2015. "Airbnb: Disruptive innovation and the rise of an informal tourism accommodation sector”. Current Issues in Tourism, 18(12), 1192-1217.

Horn, K. and Merante, M. 2017. "Is home sharing driving up rents? Evidence from Airbnb in Boston." Journal of Housing Economics, 38:14-24.

Ihlanfeldt, K.R., 2007. The effect of land use regulation on housing and land prices. Journal of Urban Economics 61, 420-435.

Kaplan, R.A. and Nadler, M.L. 2015, "Airbnb: a Case Study in occupancy regulation and taxation", No. 82, The University of Chicago Law Review Dialogue, pp. 103-15.

Koster, H., van Ommeren, J., and Volkhausen, N. 2019. Short-term rentals and the housing market: Quasiexperimental evidence from Airbnb in Los Angeles. CEPR Discussion Paper Series, DP13094.

Lee, D. 2016. "How Airbnb Short-Term Rentals Exacerbate Los Angeles's Affordable Housing Crisis: Analysis and Policy Recommendations." Harvard Law and Policy Review, 10(1):229- 253.

Morgan, B., and Kuch, D. 2015. "Radical transactionalism: Legal consciousness, diverse economies, and the sharing economy." Journal of Law and Society, 42 (4), 556-587.

Palombo , D. 2015. "A tale of two cities: the regulatory battle to incorporate short-term residential rentals into modern law". American Business Law Review 4 ( 2 ), 287 - 320 .

Quigley, J.M., Raphael, S., 2005. "Regulation and the high cost of housing in California". American Economic Review 95, 323-328.

Saiz, A., 2010. "The geographic determinants of housing supply". Quarterly Journal of Economics 125, $1253-1296$.

Segu, M. 2018. Do short-term rent platforms affect rents? Evidence from Airbnb in Barcelona. Working Paper.

Sheppard, Stephen, and Andrew Udell. 2018. "Do Airbnb Properties Affect House Prices?" Williams University working paper, January 2018.

Wachsmuth, David, David Chaney, Danielle Kerrigan, Andrea Shillolo, and Robin Basalaev-Binder. 2018. 2018. The High Cost of Short-Term Rentals in New York City. Urban Politics and Governance research group, School of Urban Planning, McGill University, January 2018.

Zervas, Georgios, Davide Proserpio, and John W. Byers, 2017, "The Rise of the Sharing Economy: Estimating the Impact of Airbnb on the Hotel Industry," Journal of Marketing Research, 2017, 54 (5), 687705. 


\section{Appendix}

Table A.1 - Summary statistics. Observations at the municipality-year-quarter level.

\begin{tabular}{lcrrrr} 
Variable & Count & Mean & S.d. & Min & Max \\
\hline Prices (sales: $€ / \mathrm{m}^{2}$ ) & 1380 & 1,273 & 526 & 374 & 3,670 \\
Prices (rents: $€ / \mathrm{m}^{2}$ ) & 1380 & 6.27 & 2.05 & 2.91 & 13.32 \\
Number of lodgings & 1380 & 49,724 & 52,960 & 7,640 & 323,981 \\
Number of Airbnb properties & 1380 & 695 & 1,420 & 2 & 9,273 \\
Number of registered properties & & & & & \\
(RNAL) & 1380 & 463 & 962 & 1 & 5,804 \\
Deteriorated houses (\%) & 1380 & 5 & 3 & 0 & 18 \\
House density (N/km2) & 1380 & 2,482 & 2,775 & 22 & 10,692 \\
Population density (N/km2) & 1380 & 4,027 & 4,001 & 36 & 14,682 \\
Housing cost (€/month) & 1380 & 433 & 55 & 321 & 589 \\
Population age & 1380 & 43 & 3 & 36 & 47 \\
House age & 1380 & 47 & 17 & 24 & 91 \\
Ageing index & 1380 & 153 & 62 & 59 & 286 \\
Dependency index (elterly) & 1380 & 31 & 9 & 16 & 50 \\
Dependency index (youth) & 1380 & 22 & 3 & 14 & 28 \\
Dependency index (total) & 1380 & 53 & 7 & 41 & 71 \\
Sustainability index & 1380 & 3.5 & 1.0 & 2.0 & 6.4 \\
Population renovation index & 1380 & 95 & 11 & 72 & 143 \\
Longevity index & 1380 & 48 & 5 & 40 & 63 \\
Number of floors per building & 1380 & 2.8 & 1.1 & 1.4 & 6.0 \\
\hline \hline
\end{tabular}


Table A. 2 - Ranking of the top 20 municipalities by Airbnb density and definition of the members of the treatment, treatment extended and placebo groups.

\begin{tabular}{|c|c|c|c|c|c|}
\hline Municipality & $\begin{array}{c}\text { Density of } \\
\text { Airbnb Q1Y04 }\end{array}$ & $\begin{array}{c}\text { Density of } \\
\text { RNAL Q1Y04 }\end{array}$ & Treatment & $\begin{array}{l}\text { Treatment } \\
\text { Extended }\end{array}$ & Placebo \\
\hline Sta Maria Maior & $12,99 \%$ & $0,00 \%$ & $\mathrm{x}$ & & \\
\hline Misericórdia & $11,34 \%$ & $0,90 \%$ & $\mathrm{x}$ & & \\
\hline Sto António & $5,42 \%$ & $0,00 \%$ & $\mathrm{x}$ & & \\
\hline UF Cedofeita, St & $3,96 \%$ & $0,00 \%$ & $\mathrm{x}$ & & \\
\hline S Vicente & $3,86 \%$ & $0,00 \%$ & $\mathrm{x}$ & & \\
\hline Arroios & $2,63 \%$ & $0,26 \%$ & $\mathrm{x}$ & & \\
\hline Lagos & $2,56 \%$ & $1,19 \%$ & & & $\mathrm{x}$ \\
\hline Albufeira & $1,76 \%$ & $2,91 \%$ & & & $\mathrm{x}$ \\
\hline Bonfim & $1,64 \%$ & $0,18 \%$ & & $\mathrm{x}$ & \\
\hline Peniche & $1,54 \%$ & $0,25 \%$ & & $\mathrm{x}$ & \\
\hline Tavira & $1,34 \%$ & $1,73 \%$ & & & $\mathrm{x}$ \\
\hline Avenidas Novas & $1,31 \%$ & $0,11 \%$ & & $\mathrm{x}$ & \\
\hline Mafra & $1,12 \%$ & $0,14 \%$ & & $\mathrm{x}$ & \\
\hline Loulé & $0,90 \%$ & $0,24 \%$ & & & $\mathrm{x}$ \\
\hline Cascais & $0,74 \%$ & $0,03 \%$ & & $\mathrm{x}$ & \\
\hline Penha de França & $0,71 \%$ & $0,06 \%$ & & $\mathrm{x}$ & \\
\hline Grândola & $0,68 \%$ & $0,15 \%$ & & $\mathrm{x}$ & \\
\hline Portimão & $0,67 \%$ & $1,84 \%$ & & & $\mathrm{x}$ \\
\hline Campolide & $0,63 \%$ & $0,00 \%$ & & $\mathrm{x}$ & \\
\hline Olhão & $0,62 \%$ & $1,01 \%$ & & & $\mathrm{x}$ \\
\hline Silves & $0,58 \%$ & $0,54 \%$ & & & $\mathrm{x}$ \\
\hline Alvalade & $0,56 \%$ & $0,01 \%$ & & $\mathrm{x}$ & \\
\hline Faro & $0,52 \%$ & $0,12 \%$ & & & $\mathrm{x}$ \\
\hline
\end{tabular}




\section{INOVA}

NOVA

School

of Business

\& Economics

Shaping

powerful

minds

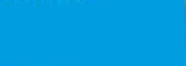

Nova School of Business and Economics

Faculdade de Economia

Universidade Nova de Lisboa

Campus de Campolide

1099-032 Lisboa PORTUGAL

Tel.: +351213801600

www.novasbe.pt 